\title{
GAMBARAN PERFORMA INSTRUKTUR KETERAMPILAN KLINIK PROGRAM STUDI PENDIDIKAN DOKTER FAKULTAS KEDOKTERAN UNIVERSITAS MALIKUSSALEH
}

\author{
Mulyati Sri Rahayu ${ }^{1}$, Yuziani $^{2}$ \\ ${ }^{1}$ Bagian Patologi Anatomi, Fakultas Kedokteran, Universitas Malikussaleh \\ ${ }^{2}$ Bagian Farmakologi, Fakultas Kedokteran, Universitas Malikussaleh
}

Corresponding Author :yuziani@unimal.ac.id

\begin{abstract}
Abstrak
Performa seorang instruktur skill lab sangat berpengaruh terhadap pencapaian sasaran pembelajaran skill lab. Tujuan penelitian ini adalah untuk mengetahui gambaran performa instruktur skill lab Program Studi Kedokteran di FK Unimal. Jenis penelitian ini adalah deskriptif-analitik menggunakan rancangan cross sectional. Responden adalah 213 mahasiswa. Instrumen yang digunakan adalah "Instrument for Evaluating Clinical Skills lab Teacher's Didactical Performance". Hasil penelitian menunjukkan performa keterampilan mengajar, keterampilan interpersonal dan komunikasi dan performa kondisi/strategi pelatihan intruktur keterampila klinik didinilai baik oleh mahasiswa dengan persentase kategori baik sampai sangat baik lebih dari $90 \%$. Kesimpulan penelitian ini menunjukkan bahwa secara umum performa instruktur keterampilan klinik di Program Studi Kedokteran FK Unimal sudah baik berdasarkan persepsi mahasiswa.
\end{abstract}

Kata kunci : keterampilan klinis, instruktur, perfoma mengajar, instrumen

\section{The Performance Of Clinical Skill Instructor In Program Studi Kedokteran At Fakultas Kedokteran Universitas Malikussaleh}

\begin{abstract}
The performance of a skill lab instructor is very influential on the achievement of skill lab learning objectives. The purpose of this study is to describe the performance of the skill lab instructor of Program Studi Kedokteran at FK unimal. This study employs quantitative descriptive research use cross sectional design. The respondents were 213 students of Medical Study Program of FK Unimal. The instrument that was used in this research is a questionnaire entitled "Instrument for Evaluating Clinical Skills Teacher's lab didactical Performance". The results of the study showed that didactil skills, interpersonal and communication skills, performance conditions / clinical skill training strategy of skill lab instructor is rated as good by students, with the percentage of good to excellent category more than $90 \%$. The conclusions of this study in general indicate that the performance of clinical skill instructor in Program Studi Kedokteran at FK Unimal is good based on the perception of students.
\end{abstract}

Keywords: clinical skills, instructor, didactical performance, instrument 


\section{PENDAHULUAN}

Keterampilan klinik merupakan prosedur atau keterampilan yang berkaitan dengan masalah kesehatan dengan menerapkan prinsip keselamatan pasien, keselamatan diri sendiri dan keselamatan orang lain (KKI,2012). Keterampilan klinik merupakan sarana mahasiswa dapat melatih keterampilanklinis, karena itu keterampilan klinik memiliki peranan yang besar dalam melatih keterampilanklinis mahasiswa kedokteran dalammencapai standar kompetensi selamajejang pendidikan S1(Setiawan et al, 2013). Seorang dokter harus berkompetensi sesuai dengan standar kompetensi yang telah ditentukan salah satunya yaitu mahasiswa mampu untuk menguasai keterampilan klinis, sebagaimana yang tercantum di dalam Standar Kompetensi Dokter Indonesia, lulusan dokter diharapkan mampu (KKI,2012):

1. Melakukan prosedur diagnosis

a. Melakukan dan menginterpretasi hasil auto-, allo- dan hetero-anamnesis, pemeriksaan umum dan khusus sesuai dengan masalah pasien

b. Melakukan dan menginterpretasi pemeriksaan penunjang dasar dan mengusulkan pemeriksaan penunjang lainnya yang rasional.

2. Melakukan prosedur penatalaksanaan masalah kesehatan secara holistik dan komprehensif

a. Melakukan edukasi dan konseling

b. Melaksanakan promosi kesehatan

c. Melakukan tindakan medis preventif

d. Melakukan tindakan medis kuratif

e. Melakukan tindakan medis rehabilitatif

f. Melakukan prosedur proteksi terhadap hal yang dapat membahayakan diri sendiri dan orang lain

g. Melakukan tindakan medis pada kedaruratan klinis dengan menerapkan prinsip keselamatan pasien

h. Melakukan tindakan medis dengan pendekatan medikolegal terhadap masalah kesehatan/kecenderaan yang berhubungan dengan hukum.

Keberhasilan pembelajaran keterampilan klinik ditentukan oleh banyak faktor yang terkait dalam proses pembelajarannya. Komponen penting yang menentukan keberhasilan suatu pelatihan keterampilan klinik diantaranya:

(1) Konten materi keterampilan

Terkait konten materi, Amin \& Khoo (2009), mengatakan bahwa keterampilan kilinik yang komplek harus dipecah menjadi komponen-komponen keterampilan yang lebih kecil 
dalam pembelajarannya kemudian seiring dengan pertambahan kemampuan mahasiswa, komponen keterampilan yang kecil-kecil ini diintegrasikan kembali. Selain itu, konten materi juga menentukan berapa lama waktu yang dibutuhkan untuk proses pelatihannya. Jika terkendala dengan keterbatasan waktu, harus dipikirkan kesempatan berlatih mahasiswa memungkinkan tidak untuk melakukan prosedur keterampilan tersebut.

(2) Metode atau strategi pelatihan

Terkait metode dalam menyampaikan latihan keterampilan klinik dikenal dengan singkatan S-T-E-P-S, yaitu menggali dan mengaktifkan pengetahuan sebelumnya (set the foundation), demonstrasi oleh intruktur (tutor demonstration), penjelasan sambil mendemonstrsikan kembali (explanation), mahasiswa mempraktekkan dibawah supervisi (practice under supervision) dan melakukan praktek kembali secara keseluruhan dengan baik (Harden \& Dent, 2009).

(3) Peserta didik

Hal-hal yang mempengaruhi peserta didik dalam penguasaan suatu keterampilan antara lain prior knowledge, yaitu pengetahuan awal atau kemampuan dasar yang sudah dimiliki sebelumnya; aptitudes atau tingkat kecerdasan keterampilan/bakat yang dimiliki mahasiswa; umur mahasiswa; gaya belajar mahasiswa serta sikap dan motivasi mahasiswa (Suryadi, 2008).

(4) Instruktur klinik

Instruktur memegang peranan sangat penting dalam pembelajaran keterampilan klinik. Terdapat 12 peran seorang dosen klinik. Kedua belas peran tersebut mencakup 6 area aktivitas dosen klinik diantaranya sebagai penyedia informasi bagi mahasiswa, dosen sebagi role model, dosen sebagai fasilitator, dosen sebagai asesor, dosen sebagai perencana serta dosen sebagai pengembang materi dan bahan pembelajaran. Kedua belas peran dosen klinik tersebut dapat dilihat pada gambar 1

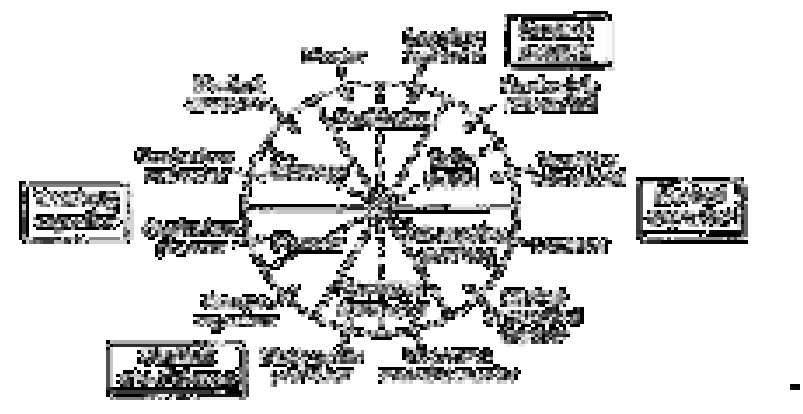

Gambar 1 Dua belas peran dosen klinik (Harden \& Crosby, 2000)

(5)Peralatan 
Peralatan memegang peranan penting dalam pencapaian keberhasilan pembelajaran keterampilan klinik. Jumlah dan jenis peralatan sebaiknya harus memadai. Peralatan tersebut berupa manikan dan barang habis pakai yang biasa digunakan. Kekurangan jumlah peralatan akan berimbas pada kurangnya kesempatan mahasiswa untuk berlatih keterampilan. Mahasiswa sulit untuk bisa menjadi mahir jika tidak diberikan kesempatan untuk berlatih (Hutchinson, 2003).

(6) Lingkungan pembelajaran

Lingkungan pembelajaran dapat berupa lingkungan fisik dan lingkungan non-fisik (sosial). Lingkungan fisik seperti ruangan, sarana dan prasarana, pencahayaaan ruangan, suhu ruangan dan ventilasi ruangan. Faktor lingkungan sosial seperti sikap dan car instruktur membawakan materi menarik, pasien simulasi yang cukup baik dan atraktif, antusiame dari tema-teman anggota kelompok, interaksi antar sesama teman anggota kelompok, dan lainnya. Kesemuanya ini dapat membangun motivasi dari peserta didik serta membuat proses pembelajarab keterampilan klinik berjalan lebih kondusif (Hutchinson, 2003).

Kegiatan keterampilan klinik yang diterapkan di Indonesia khususnya di Fakultas Kedokteran Universitas Malikussaleh merupakan mata kuliah yang dilaksanakan mulai semester 1 sampai semester tujuh. Kegiatan keterampilan klinik dilakukan 1 kali tatap muka setiap topiknya dengan durasi 100 menit setiap kegiatan dan dibimbing oleh seorang instruktur. Pada setiap pertemuan intruktur menjelaskan tujuan pembelajaran tentang materi keterampilan yang akan dilakukan, dilanjutkan dengan instruktur yang memberikan demonstrasi keterampilan dan setelahnya mahasiswa dilatih dan berlatih keterampilan tersebut menggunakan manekin dan alat-alat medis yang telah disiapkan. Penilai keterampilan klinik dilaksanakan di akhir setiap akhir semester dalam bentuk Objective Structured Clinical Examination (OSCE). Ujian Keterampilan klinik yang dilaksanakan setiap akhir semester memperlihatkan masih ada mahasiswa yang belum mencapai kompetensi minimal pada topik keterampilan klinis tertentu. Seorang instruktur dianggap memiliki peran penting dalam mencapai kompetensi tersebut. Oleh karena itu penelitian evaluatif sangat diperlukan secara berkala pada semua aspek pembelajaran PBL termasuk kegiatan keterampilan klinik terutama performa instruktur keterampilan berdasarkan persepsi mahasiswa di ProgramStudi Pendidikan Dokter Fakultas Kedokteran Universitas Malikussaleh. 


\section{METODE PENELITIAN}

Jenis penelitian yang digunakan adalah penelitian deskriptif-analitik dengan desain cross sectional survey. Penelitian ini akan dilakukan di Pogram Studi PendidikanDokterFakultas Kedokteran yang dilakukan mulai dari bulan Maret-September 2019. Sampel penelitian adalah mahasiswa ProgramStudi PendidikanDokterFakultas Kedokteran angkatan 2016, 2017 dan 2018 dengan total sampel 213 orang yang sesuai kriteria inklusi dan eksklusi. Penilaian performa instruktur Keterampilan klinik menggunakan kuisoner berupa rating scale yang diadopsi dari penelitian Ide Pustaka Setiawan dengan judul “Instrument for Evaluating Clinical Skill Laboratory Teacher's Didactical Performance" yang telah valid dan reliabel untuk menilai performa instruktur skill lab. ${ }^{4}$

\section{HASIL PENELITIAN}

I. Performa Keterampilan Mengajar

Tabel 1. Performa keterampilan mengajar instruktur keterampilan klinik

\begin{tabular}{lcc}
\hline \multirow{2}{*}{$\begin{array}{c}\text { Performa } \\
\text { Instruktur }\end{array}$} & \multicolumn{2}{c}{ Jumlah } \\
\cline { 2 - 3 } \multicolumn{1}{c}{ Sangat Baik } & n & \% \\
\hline Baik & 87 & 40,9 \\
\hline Cukup & 121 & 56,8 \\
\hline Kurang Baik & 5 & 2,3 \\
\hline Total & 0 & 0 \\
\hline
\end{tabular}

Berdasarkan tabel 1 diketahui bahwa dari 213 responden mahasiswa ada sebanyak 56,8 \% (121 mahasiswa) memberikan penilaian baik dan bahkan sebanyak 40,9 \% (87 mahasiswa) memberikan penilaian sangat baik terhadap performa keterampilan mengajar instruktur keterampilan klinik. Data tersebut juga menunjukkan tidak ada mahasiswa yang memberikan penilaian kurang baik terhadap performa keterampilan mengajar instruktur keterampilan klinik Program Studi Kedokteran di FK Unimal.

Indikator performa keterampilan mengajar instruktur keterampilan klinik Program Studi Kedokteran di FK Unimal secara rinci juga dapat dilihat dalam tabel 2.

Tabel 2 Indikator Performa keterampilan mengajar instruktur keterampilan klinik

\begin{tabular}{llccccc}
\hline \multirow{2}{*}{ Indikator } & $\begin{array}{c}\text { Sangat } \\
\text { Kurang }\end{array}$ & Kurang & Cukup & Baik & Sangat Baik \\
\cline { 2 - 6 } & $\mathrm{n}(\%)$ & $\mathrm{n}(\%)$ & $\mathrm{n}(\%)$ & $\mathrm{n}(\%)$ & $\mathrm{n}(\%)$ \\
\hline $1 \quad \begin{array}{l}\text { Mendiskusikan persiapan bahan } \\
\text { belajar/materi pembelajaran }\end{array}$ & $2(0,9)$ & $1(0,5)$ & $46(21,6)$ & $135(3,4) 6$ & $29(13,6)$ \\
\hline
\end{tabular}




\begin{tabular}{|c|c|c|c|c|c|c|}
\hline & $\begin{array}{l}\text { mahasiswa untuk membangun } \\
\text { pengetahuan, tanpa mengkritik. }\end{array}$ & & & & & \\
\hline 2 & $\begin{array}{l}\text { Menyadari tingkat pengetahuan dan } \\
\text { pemahaman mahasiswa. }\end{array}$ & 0 & $10(4,7)$ & $68(31,9)$ & $109(51,2)$ & $26(12,2)$ \\
\hline 3 & $\begin{array}{l}\text { Mendemonstrasikan keterampilan } \\
\text { klinis selangkah demi selangkah. }\end{array}$ & 0 & $1(0,5)$ & $57(26,8)$ & $110(51,6)$ & $45(21,2)$ \\
\hline 4 & Menjawab pertanyaan mahasiswa. & 0 & $2(0,9)$ & $48(22,5)$ & $99(46,5)$ & $64(30,0)$ \\
\hline 5 & $\begin{array}{l}\text { Memberikan latihan keterampilan } \\
\text { menurut teori yang mendasari. }\end{array}$ & $1(0,5)$ & $5(2,3)$ & $23(10,8)$ & $136(63,8)$ & $48(22,5)$ \\
\hline 6 & $\begin{array}{l}\text { Membantu mahasiswa dalam } \\
\text { memahami materi dan mengkoreksi } \\
\text { kesalahan. }\end{array}$ & $1(0,5)$ & $5(2,3)$ & $18(8,5)$ & $147(69,0)$ & $42(19,7)$ \\
\hline 7 & $\begin{array}{l}\text { Menstimulasi mahasiswa untuk } \\
\text { berkolaborasi. }\end{array}$ & 0 & $9(4,2)$ & $43(20,2)$ & $118(55,4)$ & $43(20,2)$ \\
\hline 8 & $\begin{array}{l}\text { Memberikan kesempatan kepada } \\
\text { mahasiswa untuk mengajukan } \\
\text { pertanyaan. }\end{array}$ & $1(0,5)$ & $1(0,5)$ & $43(20,2)$ & $108(50,7)$ & $60(28,2)$ \\
\hline 9 & $\begin{array}{l}\text { Menciptakan keseimbangan yang baik } \\
\text { antara pertanyaan dan pengajaran. }\end{array}$ & 0 & $3(1,4)$ & $57(26,8)$ & $116(54,5)$ & $37(17,4)$ \\
\hline 10 & $\begin{array}{l}\text { Memberikan umpan balik positif yang } \\
\text { membangun dan menjelaskan umpan } \\
\text { balik yang negative. }\end{array}$ & $2(0,9)$ & $2(0,9)$ & $69(32,4)$ & $97(45,5)$ & $43(20,2)$ \\
\hline 11 & $\begin{array}{l}\text { Menstimulasi pembelajaran } \\
\text { kontekstual dengan menghubungkan } \\
\text { pemeriksaan fisik dengan kondisi } \\
\text { klinis yang nyata. }\end{array}$ & 0 & $2(0,9)$ & $69(32,4)$ & $101(47,4)$ & $41(19,2)$ \\
\hline 12 & $\begin{array}{l}\text { Menjelaskan maksud dari hasil yang } \\
\text { mungkin timbul dari pemeriksaan } \\
\text { fisik }\end{array}$ & 0 & $12(5,6)$ & $48(22,5)$ & $103(48,4)$ & $50(23,5)$ \\
\hline 13 & $\begin{array}{l}\text { Meminta umpan balik pada sesi } \\
\text { pengajaran dan pelatihan }\end{array}$ & 0 & $21(9,9)$ & $55(25,8)$ & $94(44,1)$ & $43(20,2)$ \\
\hline
\end{tabular}

Dari table tersebut diketahui performa keterampilan mengajar instruktur keterampilan klinik dalam Membantu mahasiswa dalam memahami materi dan mengkoreksi kesalahan memiliki persentase tertinggi untuk kategori penilaian baik dan sangat baik dengan akumulasi persentase sebesar 88,7\% (189 mahasiswa). Performa instruktur dalam meminta umpan balik pada sesi pengajaran dan pelatihan dinilai kurang oleh mahasiswa. Indikator tersebut memiliki persentase tertinggi untuk kategori penilaian kurang yaitu sebesar 9,9 \% (21 mahasiswa). Selanjutnya, pada indikator kedua belas yaitu menjelaskan maksud dari hasil yang mungkin timbul dari pemeriksaan fisik. Sebanyak 5,6\% (12 mahasiswa) memberikan penilaian kurang pada indikator tersebut

II. Performa Keterampilan Interpersonal dan Komunikasi

Tabel 3 Performa keterampilan Interpersonal dan Komunikasi instruktur keterampilan klinik

\begin{tabular}{lcc}
\hline \multirow{2}{*}{$\begin{array}{c}\text { Performa } \\
\text { Instruktur }\end{array}$} & \multicolumn{2}{c}{ Jumlah } \\
\cline { 2 - 3 } & n & \% \\
\hline Sangat Baik & 75 & 35,2 \\
\hline Baik & 132 & 62 \\
\hline
\end{tabular}




\begin{tabular}{lcc}
\hline Cukup & 6 & 2,8 \\
\hline Kurang Baik & 0 & 0 \\
\hline Total & $\mathbf{2 1 3}$ & $\mathbf{1 0 0}$ \\
\hline
\end{tabular}

Berdasarkan tabel 3 diketahui bahwa dari 213 responden mahasiswa ada sebanyak 62 \% (132 mahasiswa) memberikan penilaian baik dan bahkan sebanyak 35,2 \% (75 mahasiswa) memberikan penilaian sangat baik terhadap performa keterampilan Interpersonal dan Komunikasi instruktur keterampilan klinik. Data tersebut juga menunjukkan tidak ada mahasiswa yang memberikan penilaian kurang baik terhadap performa Interpersonal dan Komunikasi instruktur keterampilan klinik Program Studi Kedokteran di FK Unimal.

Tabel 4 Indikator Performa keterampilan Interpersonal dan Komunikasi instruktur keterampilan klinik

\begin{tabular}{|c|c|c|c|c|c|c|}
\hline \multicolumn{2}{|r|}{ Indikator } & \multirow{2}{*}{$\begin{array}{c}\text { Sangat } \\
\text { Kurang }\end{array}$} & \multirow{2}{*}{$\begin{array}{c}\text { Kurang } \\
\mathrm{n}(\%)\end{array}$} & \multirow{2}{*}{$\begin{array}{l}\text { Cukup } \\
\mathrm{n}(\%) \\
\end{array}$} & \multirow{2}{*}{$\begin{array}{l}\text { Baik } \\
\mathrm{n}(\%)\end{array}$} & \multirow{2}{*}{$\frac{\text { Sangat Baik }}{\mathrm{n}(\%)}$} \\
\hline & & & & & & \\
\hline 1 & $\begin{array}{l}\text { Memperlakukan mahasiwa secara } \\
\text { adil. }\end{array}$ & $1(0,5)$ & $6(2,8)$ & $54(25,4)$ & $101(47,4)$ & $51(23,9)$ \\
\hline 2 & $\begin{array}{l}\text { Menghormati integritas personal } \\
\text { mahasiswa. }\end{array}$ & 0 & $4(1,9)$ & $40(18,8)$ & $126(59,2)$ & $43(20,2)$ \\
\hline 3 & $\begin{array}{l}\text { Menggunakan probandus laki-laki } \\
\text { daripada probandus perempuan }\end{array}$ & 0 & $5(2,3)$ & $18(8,5)$ & $83(39,0)$ & $107(50,2)$ \\
\hline 4 & $\begin{array}{l}\text { Meminta mahasiswa secara sukarela } \\
\text { daripada memilih atau menunjuk } \\
\text { mereka }\end{array}$ & 0 & $2(0,9)$ & $71(33,3)$ & $100(46,9)$ & $40(18,8)$ \\
\hline 5 & Menunjukkan sikap yang antusias. & 0 & 0 & $69(32,4)$ & $107(50,2)$ & $37(17,4)$ \\
\hline 6 & Memiliki selera humor & $3(1,4)$ & $11(5,2)$ & $41(19,2)$ & $126(59,2)$ & $32(15,0)$ \\
\hline
\end{tabular}

Dari tabel tersebut diketahui performa keterampilan interpersonal dan komunikasi instruktur keterampilan klinik untuk indikator lebih memilih menggunakan probandus lakilaki daripada probandus perempuan memiliki persentase tertinggi untuk kategori baik dan sangat baik dengan persentse sebesar 89,2\% (190 mahasiswa). Ada sebanyak 6,6\% (14 mahasiswa) memberi penilaian kurang dan sangat kurang pada indikator keenam yaitu memiliki selera humor. Indikator ini memiliki persentase tertinggi kategori penilaian kurang dan sangat kurang untuk performa keterampilan interpersonal dan komunikasi instruktur keterampilan klinik Program Studi Kedokteran di FK Unimal . 


\section{Performa kondisi/strategi pelatihan}

Tabel 5 Performa kondisi/strategi pelatihan keterampilan klinik

\begin{tabular}{lcc}
\hline \multicolumn{1}{c}{$\begin{array}{c}\text { Performa } \\
\text { Instruktur }\end{array}$} & \multicolumn{2}{c}{ Jumlah } \\
\cline { 2 - 3 } & n & \% \\
\hline Sangat Baik & 67 & 31,5 \\
\hline Baik & 131 & 61,5 \\
\hline Cukup & 13 & 6,1 \\
\hline Kurang Baik & 2 & 0,9 \\
\hline Total & $\mathbf{2 1 3}$ & $\mathbf{1 0 0}$ \\
\hline
\end{tabular}

Berdasarkan tabel 5 diketahui bahwa dari 213 responden mahasiswa ada sebanyak 61,5 \% (131 mahasiswa) memberikan penilaian baik dan bahkan sebanyak 31,5\% (67 mahasiswa) memberikan penilaian sangat baik terhadap performa kondisi/strategi pelatihan keterampilan klinik.

Tabel 6 Indikator Performa kondisi/strategi pelatihan keterampilan klinik

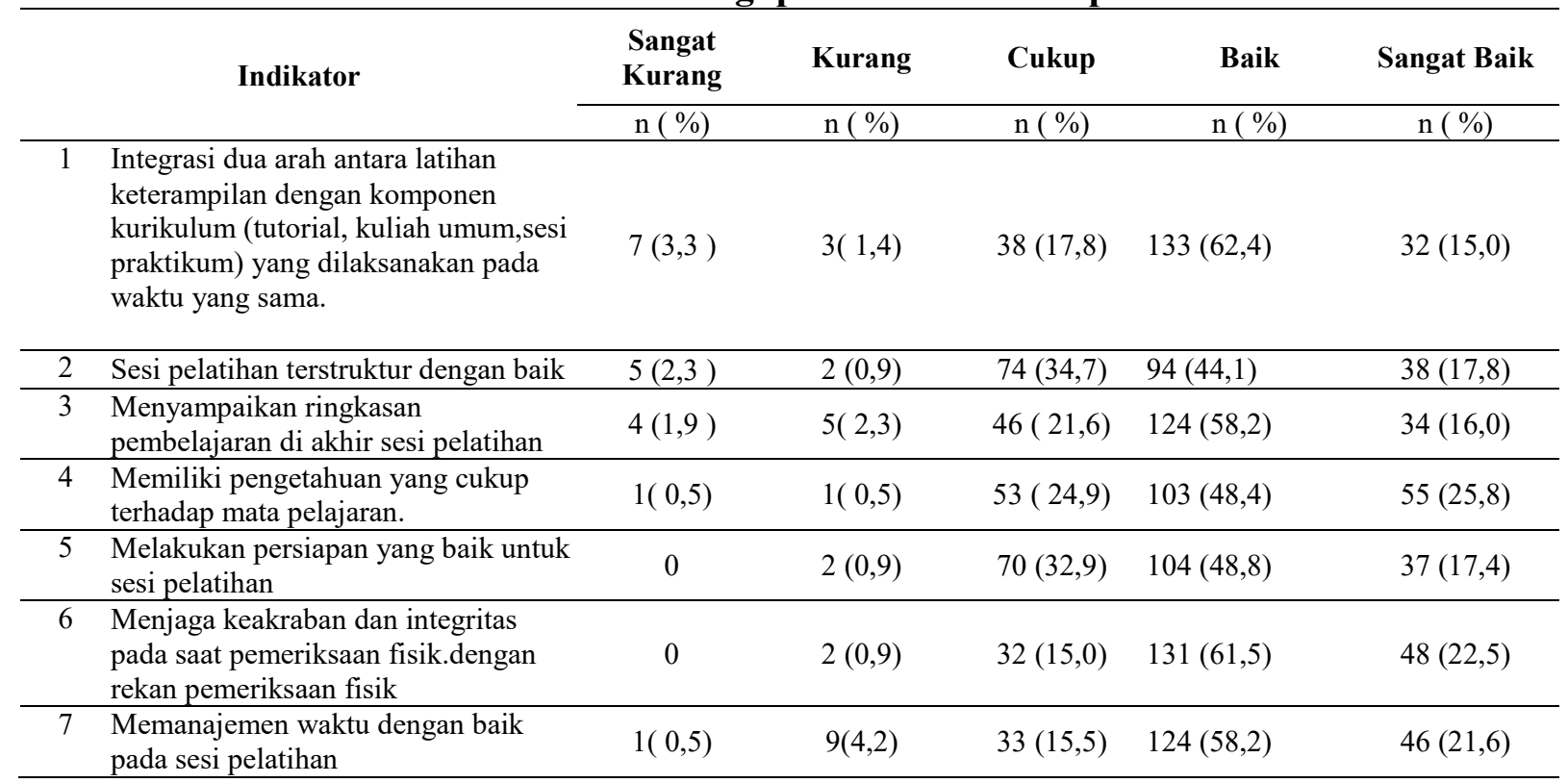

Dari tabel tersebut diketahui pada indikator keenampat yaitu menjaga keakraban dan integritas pada saat pemeriksaan fisik.dengan rekan pemeriksaan fisik memiliki persentase tertinggi untuk kategori baik dan sangat baik yaitu sebesar 84,0\% (179 mahasiswa). Sementara indikator pertama yaitu integrasi dua arah antara latihan keterampilan dengan komponen kurikulum (tutorial, kuliah umum,sesi praktikum) yang dilaksanakan pada waktu yang sama dan indikator ketujuh yaitu memanajemen waktu dengan baik pada sesi pelatihan menunjukkan 4,7 \% (10 mahasiswa) memberikan penilaian kurang dan sangat kurang terhadap performa instruktur pada indikator tersebut. 


\section{PEMBAHASAN}

\section{Performa Keterampilan Mengajar}

Hasil penelitian juga menunjukkan bahwa semua indikator keterampilan mengajar mendapat persentase $>50 \%$ pada akumulasi penilaian baik dan sangat baik. Ada beberapa kemungkinan yang menyebabkan keterampilan mengajar instruktur skill lab di Program Studi Kedokteran FK Unimal sudah baik. Pertama, proses perekrutan tenaga dosen yang baik yaitu dosen sebaiknya mempunyai kualifikasi yang diperlukan dalam penyampaian ilmu kepada mahasiswanya (Sadiman et al, 2011). Kedua, pengembangan sumber daya tenaga pendidik (instruktur keterampilan klinik) melalui proses pendidikan dan pelatihan. Ketiga, instruktur memiliki strategi/persiapan mengajar yang baik. Keempat, instruktur mau untuk terus mengembangakan ilmu pengetahuan dan keterampilan yang ia miliki serta mau untuk terus belajar.

Keterampilan mengajar instrukur skill lab Program Studi Kedokteran di FK Unimal masih kurang pada beberapa bagian diantaranya; performa instruktur dalam meminta umpan balik pada sesi pengajaran dan pelatihan dinilai kurang oleh mahasiswa. penilaian kurang yaitu sebesar Ada sekitar 9,9\% (21 mahasiswa) yang memberi penilaian kurang pada indikator tersebut. Pada saat mengajar seorang instruktur penting untuk meminta feedback kepada mahasiswa, untuk mengetahui sejauh mana pemahaman mahasiswa terhadap materi yang diajarkannya dan untuk mengetahui bagaimana performanya dalam mengajar. Melalui pemberian umpan balik maupun meminta umpan balik maka pengajar dapat membantu mahasiswa dalam pencapaian sasaran belajar (Agnesia \& Nyimas, 2016).

\section{Performa Keterampilan Interpersonal dan Komunikasi}

Secara umum keterampilan interpersonal dan komunikasi instrukur keterampilan klinik Program Studi Kedokeran di FK Unimal sudah baik, akan tetapi masih ada indikator menunjukkan bahwa keterampilan interpersonal dan komunikasi instrukur keterampilan klinik Program Studi Kedokeran di FK Unimal masih kurang yaitu pada indikator nomor enam mengenai selera humor yang dimiliki oleh instruktur yaitu ada sebanyak $6,6 \%$ (14 mahasiswa) yang memberikan penilaian kurang dan sangat kurang pada indikator tersebut.

Keterampilan interpersonal dan komunikasi sangat penting bagi seorang instrukutr keterampilan klinik. Seorang instruktur harus mampu menyampaikan informasi, ide, gagasan dan emosi secara baik dan benar. Hal ini penting untuk menciptakan suasana belajar yang aktif, komunikatif dan nyaman bagi mahasiswa. Untuk itu, seorang instruktur harus bisa meredakan ketegangan dan kecemasan suasana pembelajaran di keterampilan klinik. 
Instruktur yang memiliki selera humor yang baik dapat mencairkan suasana pembelajaran sehingga lebih menyenangkan (Sadiman, 2011).

\section{Performa Kondisi/ Strategi Pelatihan}

Hasil penelitian tersebut menunjukkan bahwa metode, teknik, perencanaan dan pelaksanaan pelatihan keterampilan klinis yang dilakukan oleh instruktur keterampilan klinik Program Studi Kedokeran di FK Unimal sudah cukup baik tetapi perlu dimaksimalkan lagi. Hal ini dapat dilihat dari persentase akumulasi penilaian baik dan sangat baik pada setiap indikator melebihi 60\%. Ada beberapa kemungkinan yang menyebabkan performa kondisi/strategi pelatihan keterampilan klinis instruktur keterampilan klinik dalam penelitian ini sudah baik. Pertama, pelatihan dan pendidikan keterampilan klinik yang pernah diikuti oleh instruktur keterampilan klinik Program Studi Kedokteran di FK Unimal. Kedua, kemampuan kognitif dan psikomotorik instruktur yang baik. Ketiga, keterampilan instruktur dalam menggunakan dan memaksimalkan sarana dan prasarana yang tersedia. Keempat, keakraban dan keharmonisan hubungan serta komunikasi yang baik antar instruktur keterampilan klinik. Terakhir, kesungguhan hati/keseriusan instruktur dalam mendedikasikan ilmu dan keterampilan yang ia miliki kepada mahasiswa.

Sementara itu, performa kondisi/strategi pelatihan keterampilan klinis instruktur FK Unimal masih kurang pada beberapa indikator diantaranya indikator nomor tujuh dalam memanajemen waktu dengan baik pada sesi pelatihan. Ada sekitar 4,7\% (10 mahasiswa) yang memberikan penilaian kurang dan sangat kurang kurang pada indikator tersebut. Masalah manajemen waktu yang kurang baik pada saat keterampilan klinis tidak hanya terjadi di Program Studi Kedokteran FK Unimal saja tetapi juga terjadi di FK Unand. Penelitian Hardisman (2013) menyebutkan bahwa hambatan dalam pelaksanaan keterampilan klinis yang dialami mahasiswa terutama disebabkan oleh kehadiran instruktur yang tidak tepat waktu ataupun penggantian jadwal dengan alokasi waktu yang tidak sesuai.

Ada beberapa hal yang mungkin menjadi penyebab mengapa instruktur keterampilan klinis di Program Studi Kedokteran FK Unimal masing kurang dalam menyampaikan ringkasan pembelajaran di akhir sesi pelatihan dan memanajemen waktu dengan baik pada saat sesi pelatihan keterampilan klinis. Pertama, jumlah dosen yang menjadi instruktur keterampilan klinis Program Studi Kedokeran di FK Unimal. Jumlah dosen di FK Unimal bisa dibilang masih sangat minim dengan kebutuhan institusi. Kedua, kesibukan instruktur keterampilan klinis. Sebagian instruktur tersebut juga bertanggung jawab dalam pelayanan kesehatan di Rumah Sakit Pendidikan sekaligus berkewajiban sebagai klinik bagi mahasiswa 
program studi profesi. Dosen yang menjadi instruktur keterampilan klinis juga memiliki beberapa tugas lain seperti mengajar, menjadi tutor, dan juga sebagai tenaga pengajar saat praktikum. Satu orang dosen bisa memiliki beberapa peran, baik peran dalam hal mengajar maupun peran dalam hal struktural. Kesibukan instruktur keterampilan klinis tersebut masih mencakup kehidupan kampus, belum termasuk kesibukan pribadi seperti praktek pribadi mereka atau keluarga mereka. Ketiga, materi keterampilan klinis yang padat sehingga tidak cukup waktu untuk menyampaikan ringkasan pembelajaran pada akhir sesi pelatihan. Akan tetapi, hal ini masih harus diteliti lebih dalam lagi.

\section{KESIMPULAN}

Berdasarkan hasil penelitian dan pembahasan, didapatkan kesimpulan dari hasil penelitian ini sebagai berikut:

1. Sebanyak 97,6\% (208 mahasiswa) memberikan penilaian baik terhadap performa keterampilan mengajar, sebanyak 97,2\% (207 mahasiswa) memberikan penilaian baik terhadap keterampilan interpersonal dan komunikasi instruktur serta sebanyak 93,0\% (198 mahasiswa) memberikan penilaian baik terhadap performa kondisi/strategi pelatihan keterampilan instruktur keterampilan klinis Program Studi Kedokteran di Fakultas Kedokteran Universitas Malikussaleh.

2. Performa terbaik instrukur terdapat pada indikator performa keterampilan interpersonal dan komunikasi yaitu instruktur lebih menggunakan model laki-laki daripada model perempuan dengan akumulasi penilaian baik sampai sangat baik sebesar 89,2\%.

3. Performa instruktur yang paling kurang terdapat pada indikator performa keterampilan mengajar yaitu dalam meminta umpan balik pada sesi pengajaran dan pelatihan. Ada Sebanyak 9,9\% mahasiswa memberikan penilaian kurang sampai sangat kurang terhadap indikator tersebut.

\section{SARAN}

Berdasarkan hasil penelitian yang telah dilakukan, maka dapat peneliti sarankan sebagai berikut:

1. Diharapkan bagi mahasiswa dapat mempersiapkan diri dengan baik terkait topik keterampilan klinik yang akan diberikan sehingga kompetensi skill yang diberikan dapat tercapai dengan baik. 
2. Hasil penelitian ini diharapkan dapat menjadi umpan balik bagi tim Medical Education Unit untuk mengevaluasi pelaksanaan keterampilan klinik serta meningkatkan kualitas dan kuantitas tenaga pengajar di FK Unimal.

3. Penelitian dengan wawancara mendalam secara kualitatif dapat dilakukan untuk menggali lebih dalam lagi mengenai hal-hal yang menyebabkan performa instruktur keterampilan klinis Program Studi Kedokteran di FK Unimal masih kurang pada beberapa indikator.

\section{REFERENSI}

1. Agnesia, F.P., Nyimas, N.A.S., 2016. Gambaran performa instruktur skill lab program studi kedokteran di fakultas kedokteran dan ilmu kesehatan universitas jambi . $J M J$, Vol. 4, No 1, pp: $15-27$

2. Amin, Z., Khoo, H.E., 2009. Basic in medical education. Edisi ke-2, Singapore : World Scientific Publising.

3. Harden, R.M., Dent, J.A., 2009. A practical guide for medical teachers. Edisi ke-3,UK: Churcill Livingstone.

4. Harden, R.M, Crosby, J., 2000. AMEE education guide no.20: the good teacher is more than a lecturer: the twelve roles of the teacher. (Med Teach) Vol. 22, No.4,pp.334-347.

5. Hardisman, Yulistini., 2013. Pandangan mahasiswa terhadap hambatan pada pelaksanaan skill lab di Fakultas Kedokteran Universitas Andalas. (Jurnal Pendidikan Kedokteran Indonesia) Vol. 2, No.3, pp:187-180

6. Hutchinson, L., 2003. Education environment. Dalam: Cantillon P, Hutchinson L, Wood $D$, editor. ABC of learning and teaching in medicine, London: BMJ Publishing Group

7. KKI. 2012. Standar Kompetensi Dokter Indonesia. Jakarta: Konsil Kedokteran Indonesia

8. Mc.Cluskey, Editor: David, R., 2008. Kemampuan praktis esensial dalam OSCE di bidang kedokteran, Jakarta: EGC

9. Sadiman, A., 2011. Media pendidikan: pengertian, pengembangan, dan pemanfaatannya, Jakarta: Rajawali Pers.

10. Setiawan,P., Danlen J.V., Wittingham, J,. 2013. Instrument for evaluating didactical performance of clinical skill laboratory teachers.( Jurnal Pendidikan Kedokteran Indonesia) Vol.2, No.2, pp.95-85

11. Suryadi, E., 2008. Pendidikan di laboratorium keterampilan klinik, Yogyakarta: Fakultas Kedokteran Universitas Gadjah Mada. 